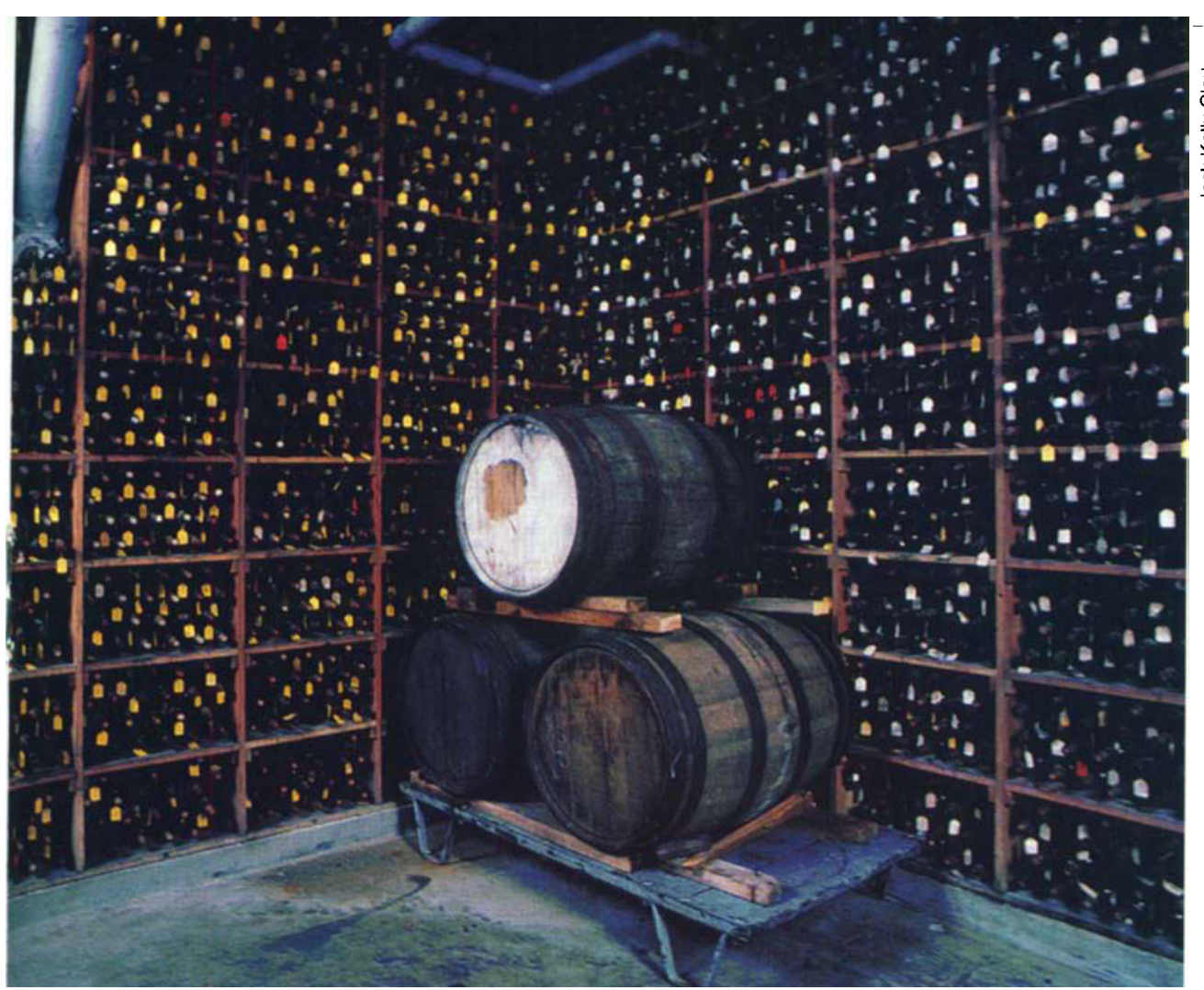

\section{Contract use widespread in wine grape industry}

\author{
Rachael E. Goodhue $\quad \square \quad$ Dale M. Heien \\ Hyunok Lee a Daniel A. Sumner
}

\begin{abstract}
The use of agricultural contracts between farmers and processors or other buyers has increased substantially in recent years. Roughly half of all U.S. fruit and vegetable production is under contract. Contract usage varies widely across agricultural products. For example, $95 \%$ of poultry is raised under contract while only $13 \%$ of corn is. The wine grape industry utilizes contracts, yet little is known about the extent of contract use, or the use of specific terms and objectives. We used a survey to analyze contract use among wine grape producers, determine which users are utilizing contracts, and identify how they differ from nonusers. Ninety percent of the growers who responded to the survey have contracts, the majority of which were multiyear, averaging 3.7 years. Growers with more experience, larger vineyards, more expensive grapes and longer relationships with the buyer were more likely to enter into contracts.
\end{abstract}

Ninety-six percent of U.S. wine grapes are grown in California. Like many other agricultural commodities, the wine grape industry utilizes contracts to codity the relationship between growers and buyers. Wine is stored in cellars, such as this one at UC Davis, built in 1938.

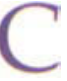
ontracts between agricultural producers and processors are becoming more common. Generally, these contracts specify one or more conditions of sale, such as the price, and/or production methods, such as the trellising system. As the use of contracts increases nationwide, agricultural observers have expressed growing concerns about the impact of these arrangements on risk and returns (USDA 2000). While several theoretical studies address these issues, relatively few have examined agricultural contracts empirically (Knoeber and Thurman 1994; Goodhue 1997, 1999).

The California wine grape industry provides a good case study of contract use, as wine grapes are an economically significant crop for the state. With a production value of $\$ 2.7$ billion in 1999, grapes are the most valuable U.S. fruit crop, and more than three-fourths of the grape crop's value comes from wine grapes.

Ninety-six percent of U.S. wine grapes are grown in California (Sumner et al. in press). In 1997, grapes were California's second largest agricultural product in terms of production value (Heien 1999).

\section{Economic aspects}

The economic literature on agricultural contracts often is based on the presumption that information differences exist between the parties involved in a transaction, and that these differences may result in incentive problems. Specifically, the profits of one party, the "principal," are dependent on information known only to the 
other party, the "agent." In the cases analyzed, the agent will not act in the principal's best interests unless provided with an incentive to do so, such as a payment linked to the principal's profits. More recently, interest has extended to the way U.S. agriculture is organized economically (Boehlje 1995, 1996; Barkema et al. 1993; Barkema 1994; Barry 1995; Boehlje and Schrader 1998;

Drabenstott 1994, 1995; Urban 1991).

Greater vertical integration and coordination has coincided with a movement away from a homogeneous commodity system to one emphasizing product differentiation. Increased coor dination between buyers and sellers allows sellers to tailor their production to buyers' needs. In the case of wine grapes, contracts between growers and vintners help growers to deliver grapes with the quality attributes that vintners want, by means of cultural-practice requirements (such as trellising method), and price bonuses and penalties based on grape attributes (such as sugar and acid)(Goodhue 1999).

The California wine grape industry clearly produces a differentiated product, as a casual comparison of the average California supermarket's wine and produce aisles will confirm. A significant proportion of this differentiation is generated at the farm level, by variables such as region and variety. The quality of wine grapes is partly based on observable characteristics sugar content (brix), acid and $\mathrm{pH}-$ while more subtle characteristics are harder to measure. With no explicit industrywide grading process that links quality to these characteristics, individual wineries use standards that may be specified in contracts.

\section{Wine grape grower survey}

In June 1999, the UC Agricultural Issues Center conducted a survey of contract use in the California wine grape industry. The survey questionnaire was mailed to the 12,000 growers

TABLE 1. Regional distribution of wine grape growers, 1999 survey

\begin{tabular}{lcccccc}
\hline \hline Region & Source & All & $\begin{array}{c}\text { North } \\
\text { Coast }\end{array}$ & $\begin{array}{c}\text { Central } \\
\text { Coast }\end{array}$ & $\begin{array}{c}\text { San Joaq. } \\
\text { central }\end{array}$ & $\begin{array}{c}\text { San Joaq. } \\
\text { south/other }\end{array}$ \\
\hline Acres & CASS" & 752,000 & 96,000 & 65,000 & 103,000 & 488,000 \\
\hline Total no. growers & CASS & 11,726 & 3,430 & 1,018 & 1,834 & 5,444 \\
\hline Grower respondents & Survey & 1,362 & 341 & 144 & 353 & 524 \\
\hline$\%$ growers & CASS & $100 \%$ & 29 & 9 & 16 & 46 \\
\hline$\%$ respondents & Survey & $100 \%$ & 25 & 11 & 26 & 38 \\
\hline Acres/grower & CASS & 64 & 28 & 64 & 56 & 90 \\
\hline Acres/grower & Survey & 118 & 59 & 107 & 109 & 179 \\
\hline "California Agricultural Statistics Service. & & & & & \\
\hline
\end{tabular}

and winery owners listed in the California Agricultural Statistics Service (CASS) grape acreage database. This database includes all known grape growers and wineries in the state. About $10 \%$ of the total are engaged in winemaking, either as an independent winery that purchases all of its grapes, or as a winery that produces at least some of the grapes used in its wine. The center received more than 2,000 responses, nearly $20 \%$ of the surveys mailed out. To ensure a good response rate, the questionnaire was one page with 18 questions, mostly yes/no (Goodhue et al. 1999).

The respondents were divided into four regions. In order of declining average price per ton for wine grapes, the regions are North Coast, Central Coast, central San Joaquin Valley, and southern San Joaquin Valley plus other areas, such as San Diego County. Napa and Sonoma counties, perhaps the most famous wine-growing regions, are included in the North Coast. Generally, California's premium grapes are grown in coastal areas (North and Central Coast regions), while the lower-priced grapes are grown in the Central Valley (central San Joaquin, southern San Joaquin, and others).

The percentage response from each region closely matches the grower

The authors found that $90 \%$ of surveyed growers produce wine grapes under contract. population percentage in that region (table 1). This is one indication that our survey is roughly representative of the population of growers. Within each region the survey respondents were generally operators of larger vineyards, as indicated by acres per grower, than the average grower in that region. However, the relative sizes across regions in the CASS data are similar to our survey's relative acres per grower across regions.

The survey included questions on contract use, contract provisions and grower characteristics. Growers were asked the varieties they produced, total acreage, the length of their current buyer-seller relationship and the length of time they have been in the grape business. Contract use was re-

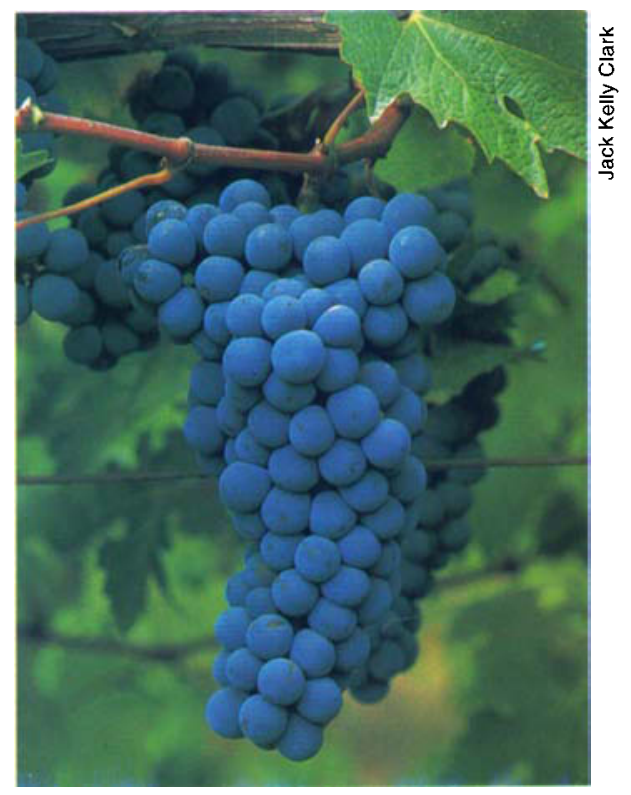




\section{"Contracts are more likely to specify production practices in premium grape-growing regions, while price incentive provisions are more common in nonpremium regions."}

\begin{tabular}{|c|c|c|c|c|c|}
\hline & All & $\begin{array}{l}\text { North } \\
\text { Coast }\end{array}$ & $\begin{array}{c}\text { Central } \\
\text { Coast }\end{array}$ & $\begin{array}{l}\text { San Joaq. } \\
\text { central }\end{array}$ & $\begin{array}{l}\text { San Joaq. } \\
\text { south/other }\end{array}$ \\
\hline No contract & 10 & 4 & 11 & 6 & 18 \\
\hline Written only & 70 & 71 & 56 & 68 & 74 \\
\hline Oral only & 11 & 13 & 20 & 15 & 4 \\
\hline Both & 9 & 12 & 13 & 11 & 4 \\
\hline Planting contract & 10 & 9 & 13 & 21 & 8 \\
\hline Evergreen clause & 30 & 45 & 34 & 13 & 9 \\
\hline
\end{tabular}

\begin{tabular}{lcccccc}
\multicolumn{5}{c}{ TABLE 3. Average farm characteristics and years of contracts } \\
\hline \hline Farm characteristics & All & $\begin{array}{c}\text { North } \\
\text { Coast }\end{array}$ & $\begin{array}{c}\text { Central } \\
\text { Coast }\end{array}$ & $\begin{array}{c}\text { San Joaq. } \\
\text { central }\end{array}$ & $\begin{array}{c}\text { San Joaq. } \\
\text { south/other }\end{array}$ \\
\hline Years with buyer & 9.7 & 7.9 & 7.5 & 12.3 & 9.6 \\
\hline Years in business & 20.6 & 18.3 & 15.8 & 21.1 & 23.6 \\
\hline Regional price (\$/ton) & 787 & 1.710 & 1,256 & 477 & 276 \\
\hline Years of contract & 3.7 & 4.0 & 4.5 & 4.8 & 2.5 \\
\hline
\end{tabular}

ported for written contracts, oral contracts, both and neither. Oral contracts are verbal arrangements made prior to the time of sale that specify one or more conditions of sale or production. Most commonly, oral contracts specify the delivery price. Some respondents had multiple buyers (or sellers), which in some cases meant that an individual used both a written and an oral contract.

The survey also included questions on contract provisions such as price incentives, bonuses and penalties; evergreen renewal clauses, which provide for automatic renewal unless one or both parties opt out; clauses specifying viticultural practices; and price determination methods, such as a price tied to last year's crush price, or a fixed price per ton.

Our survey data show that $90 \%$ of surveyed growers produce wine grapes under contract, and that most of those contracts are written (table 2). About $10 \%$ of the written contracts are planting contracts, which are signed prior to the establishment of the vineyard.

Planting contracts help growers secure financing for new vineyard development; this percentage is highest in the Central Valley where the share of new wine-grape acreage is also high. Contracts with evergreen clauses are common, accounting for $30 \%$ of all contracts, and as much as $45 \%$ on the North Coast.

We obtained the regional price of wine grapes using price data from the Final Grape Crush Report (CDFA 1999). These data represent average transac- tion prices per ton for the region. Comparison of the regional averages, acres and regional ton price shows a distinct pattern: farm size becomes smaller as regional prices increase (tables 1 and 3). Sellers have been in the grape-growing business for an average of 20.6 years; this number varied little by region.

The extent of bonuses and penalties for sugar, acids, material other than grapes (MOG) and defects (such as rot and mildew) are also important contract features. Penalties are more prevalent than bonuses, although $33 \%$ of contracts in the southern San Joaquin region provide for a sugar bonus (table 4). Overall, only about $10 \%$ of contracts have bonus provisions, while over $35 \%$ have penalty provisions. Price provisions are largely in two categories: fixed in contract or adjusted yearly. Fixed in contract means that the buyer and seller agree to a fixed price or a fixed price schedule over time. The majority of the contracts have price provisions that adjust yearly, often on the basis of a reference price such as last year's average crush price.

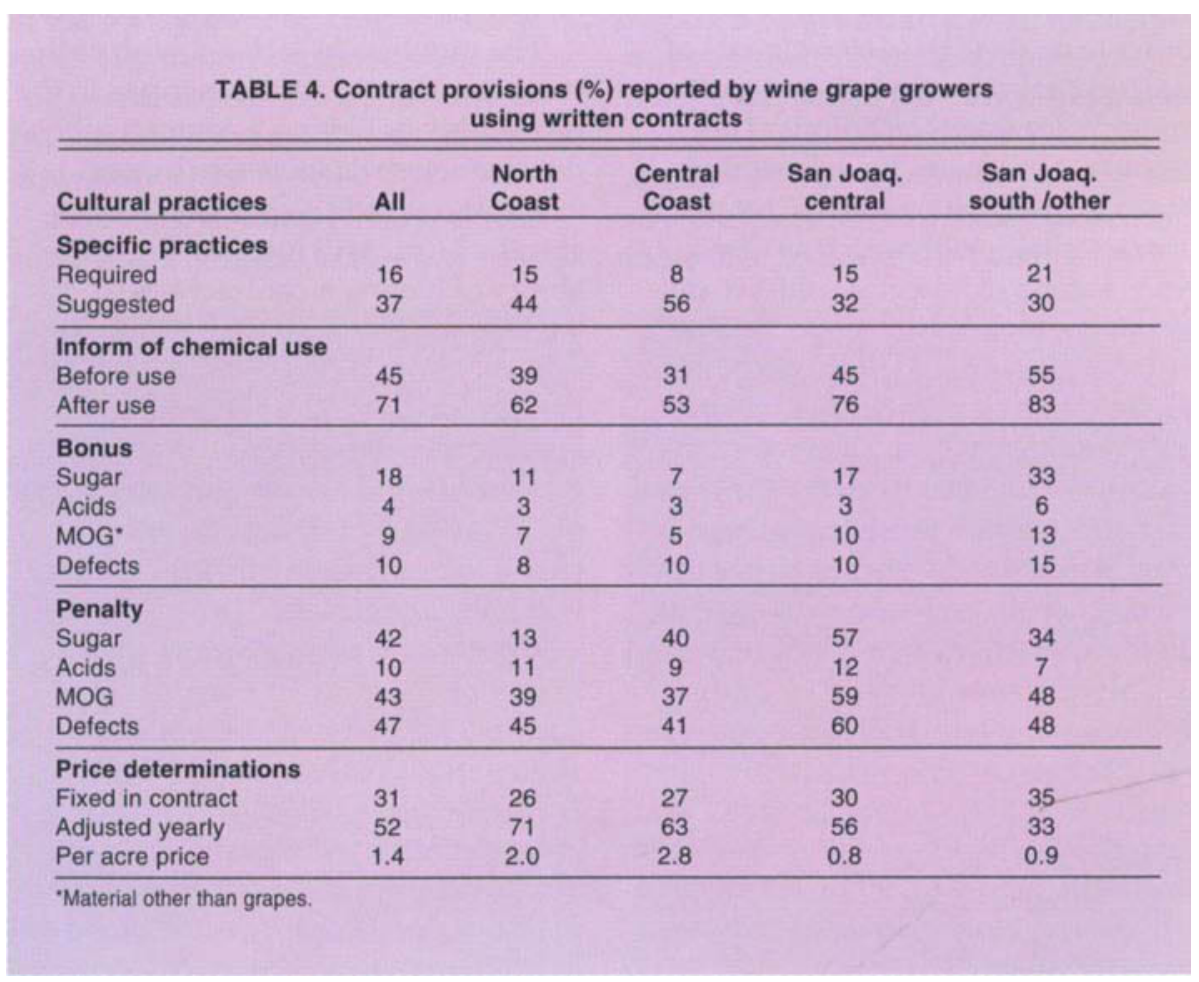




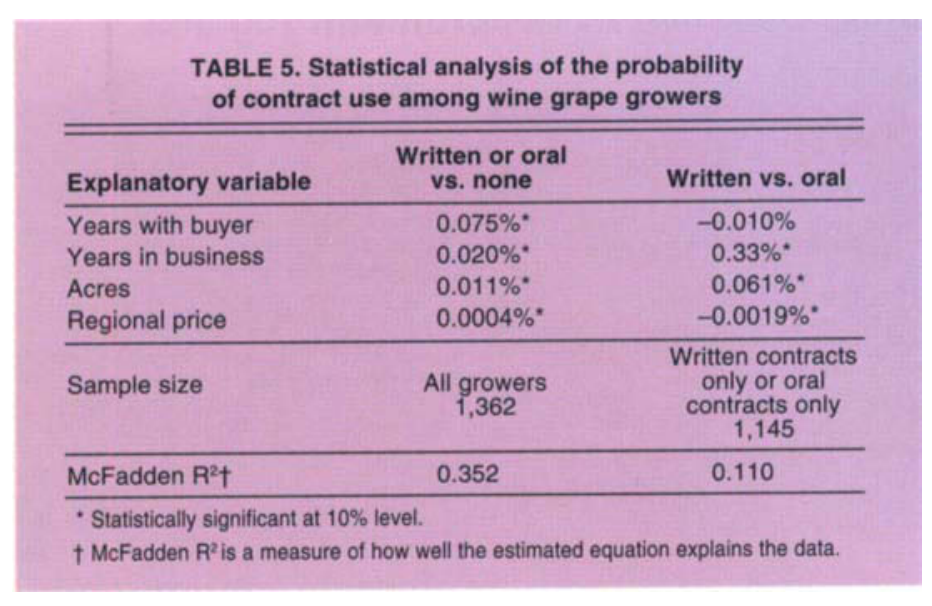

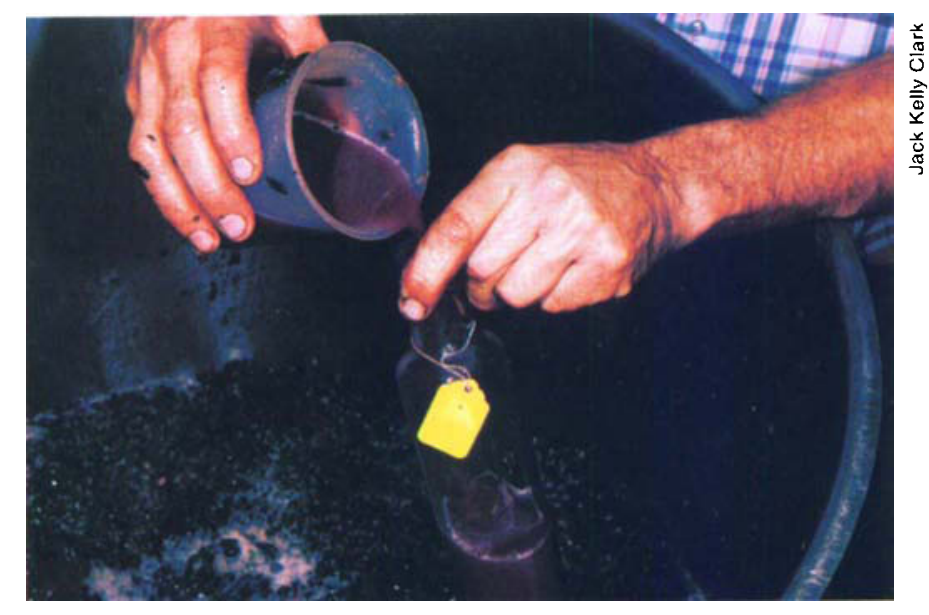

The wine industry values variety and differentiation, rather than a uniform product. The quality of wine grapes is measured in terms of sugar content, acid, pH and other less tangible characteristics. Many grower contracts require specific quality attributes.

\section{Contract provision determinants}

While contracts are the norm, their forms vary. Some are written and others are oral, some have price incentives such as penalties or bonuses and others use provisions specified in nonprice terms, such as viticultural practices. We have drawn some statistical inferences regarding which factors influence contract provisions.

As noted, most of our data consisted of yes or no answers. This includes important information, such as the inclusion of specific provisions. In order to analyze the determinants of yes / no choices, we employed a discrete choice (logit) technique. This technique estimates the probability that a grower with a specific set of characteristics will have a written contract, enter a fixed-price contract and so on. We looked first at factors that influence whether a grower produces under contract, and whether the contract is written or oral. Then we examined the factors that influence the choice of contract terms such as price incentives, winery involvement and price determination. In each case we sought to discover which characteristics are statistically significant. Our survey did not ask for price information because we expected that question to be particularly sensitive for respondents. Instead we matched the region of the grower with the crush district price. In our analysis, a higher regional price is an indication of better quality.
There are three categories for contract use: no contract, oral contract or written contract. For our statistical analysis, we omit respondents who used both written and oral contracts. The remaining three categories can be viewed as a sequence of stages. Each stage involves dichotomous outcomes, contract or no contract for the first stage, and, for those with contracts, whether the contract is oral or written in the second stage (table 5). In the first equation, all four characteristics have a positive but very small effect on the probability of having a contract.

The numbers associated with each characteristic report the increase in the probability of having a contract when the characteristic increases by one. For example, one additional year with a specific buyer will increase the probability of having a contract by $0.075 \%$. All characteristics are statistically significant at the $10 \%$ level. This means that we are over $90 \%$ certain that the specific characteristic has an impact different from zero. An increase in any one of these characteristics will increase the probability that the grower will have a contract.

Contract type. Regarding the likelihood of engaging in a written contract as opposed to an oral one, our results indicate that the contract type is closely related to grower and farm characteristics. All explanatory variables, except years with buyer, are statistically significant. The likelihood of engaging in written contracts increases with business experience and vineyard size, but decreases with the price of wine grapes.

Quality control. We examined quality control issues based on bonuses and penalties, cultural practices and price determination. For these three equations, we included additional characteristics (independent variables): whether the contract includes an evergreen clause, whether the contract is tied to planting and the length of the contract (tables 6 and 7). These variables are also binary (a grower either has a planting contract or doesn't have one). Hence, the effect is discrete. For example, if the grower has a planting contract, the probability of a specific production practice being required increases by $9.57 \%$ (table 6 ).

About half of the contracts had a provision suggesting or requiring specific grower practices. Such provisions are significantly more likely when the contract also has an evergreen provision and when the grapes are from a high-priced district (table 6). Years with buyer, years in business and presence of a planting contract also have positive effects. Also, because planting contracts apply to new vineyards, their positive effect may mean that requiring or suggesting specific production practices is a relatively new phenomenon.

Quality characteristics such as sugar, acids, MOG and defects are observable at harvest, so they can be verified at that time. For the "any bo- 
In regions that grow higher-quality grapes, such as Napa and Sonoma, contracts are more likely to include quality-related production requirements and less likely to include price incentives. Buena Vista Winery, near Sonoma, was established in 1857.

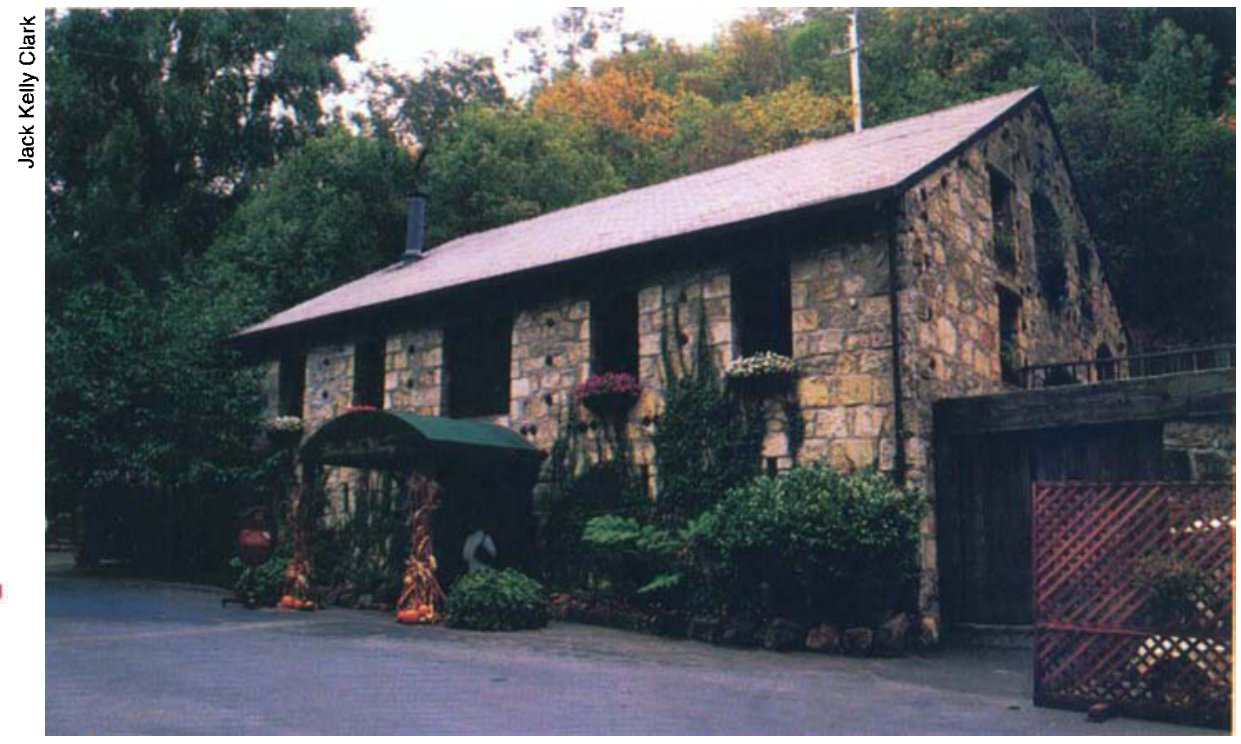

quality attributes are more easily measured and less use of price incentives where the most important quality attributes cannot be measured well at the point of delivery. According to viticulture and enology experts, sugar content is the most important product characteristic for lower-priced grapes and in regions that generally produce lower-quality wine. Sugar content is measured at harvest, when the winery crushes the grapes. In the premium grape regions, quality is often based on the historical track record of the vineyard. For grapes used to make the more expensive wines, sugar and similar easily measured characteristics are not necessarily the most important factors.

Price provisions. Finally, almost all written contracts have some type of is that we would expect more use of price incentives in those regions where

TABLE 6. Production specifications and price incentives in written wine grape grower contracts

\begin{tabular}{|c|c|c|}
\hline \multirow[b]{2}{*}{ Explanatory variable } & \multicolumn{2}{|c|}{ Effect on probability of contract having a specific clause } \\
\hline & $\begin{array}{l}\text { Specific production practices } \\
\text { required/suggested }(\%)\end{array}$ & $\begin{array}{l}\text { Bonuses or penalties } \\
\text { for quality attributes (\%) }\end{array}$ \\
\hline $\begin{array}{l}\text { Contract characteristic } \\
\text { Planting contract } \\
\text { Evergreen clause } \\
\text { Years of contract }\end{array}$ & $\begin{array}{l}9.57^{\circ} \\
9.32^{\circ} \\
0.45\end{array}$ & $\begin{array}{l}8.30^{\circ} \\
4.49^{\circ} \\
0.55^{\circ}\end{array}$ \\
\hline $\begin{array}{l}\text { Grower characteristic } \\
\text { Years with buyer } \\
\text { Years in business } \\
\text { Acres } \\
\text { Regional price }\end{array}$ & $\begin{array}{l}0.40^{*} \\
0.22^{*} \\
-0.0076 \\
0.0077^{*}\end{array}$ & $\begin{array}{l}0.22 \\
0.422^{*} \\
0.047^{*} \\
-0.0046^{\circ}\end{array}$ \\
\hline Sample size & 976 & 976 \\
\hline McFadden $\mathrm{R}^{2} \dagger$ & 0.032 & 0.14 \\
\hline
\end{tabular}

price provisions. We grouped observations with written contracts into two groups: fixed price provisions and nonfixed price provisions. Nonfixed price provisions include reference prices that are adjusted yearly, and per acre prices that do not depend on the harvested tons. Our results indicate that a fixed price provision (dependent variable $=1$ ) is less likely when the contract also is a planting contract, or when the contract has an evergreen clause (table 7). Fixed price provisions are also less likely when the farmer has more years dealing with the same buyer. However, the fixed price is more likely when the farmer has more years in the grape-growing business and has a larger vineyard. The negative effects of most of these characteristics may indicate that fixed price

\begin{tabular}{|c|c|}
\hline \multicolumn{2}{|c|}{$\begin{array}{l}\text { TABLE 7. Price provisions in written } \\
\text { wine grape grower contracts }\end{array}$} \\
\hline Explanatory variable & $\begin{array}{l}\text { Effect on probability } \\
\text { of contract including } \\
\text { fixed price provision }\end{array}$ \\
\hline \multicolumn{2}{|l|}{ Contract characteristic } \\
\hline Planting contract & $-14.84^{*}$ \\
\hline Evergreen clause & $-24.46^{\circ}$ \\
\hline Years of contract & -0.35 \\
\hline \multicolumn{2}{|l|}{ Grower characteristic } \\
\hline Years with buyer & $-0.99^{*}$ \\
\hline Years in business & $0.57^{*}$ \\
\hline Acres & $0.057^{*}$ \\
\hline Regional price & -0.0023 \\
\hline Sample size & 976 \\
\hline McFadden $\mathrm{R}^{2} \dagger$ & 0.094 \\
\hline \multicolumn{2}{|c|}{$\begin{array}{l}\text { Statistically significant at the } 10 \% \text { level. } \\
\text { † McFadden } R^{2} \text { is a measure of how well the estimated } \\
\text { equation explains the data. }\end{array}$} \\
\hline
\end{tabular}




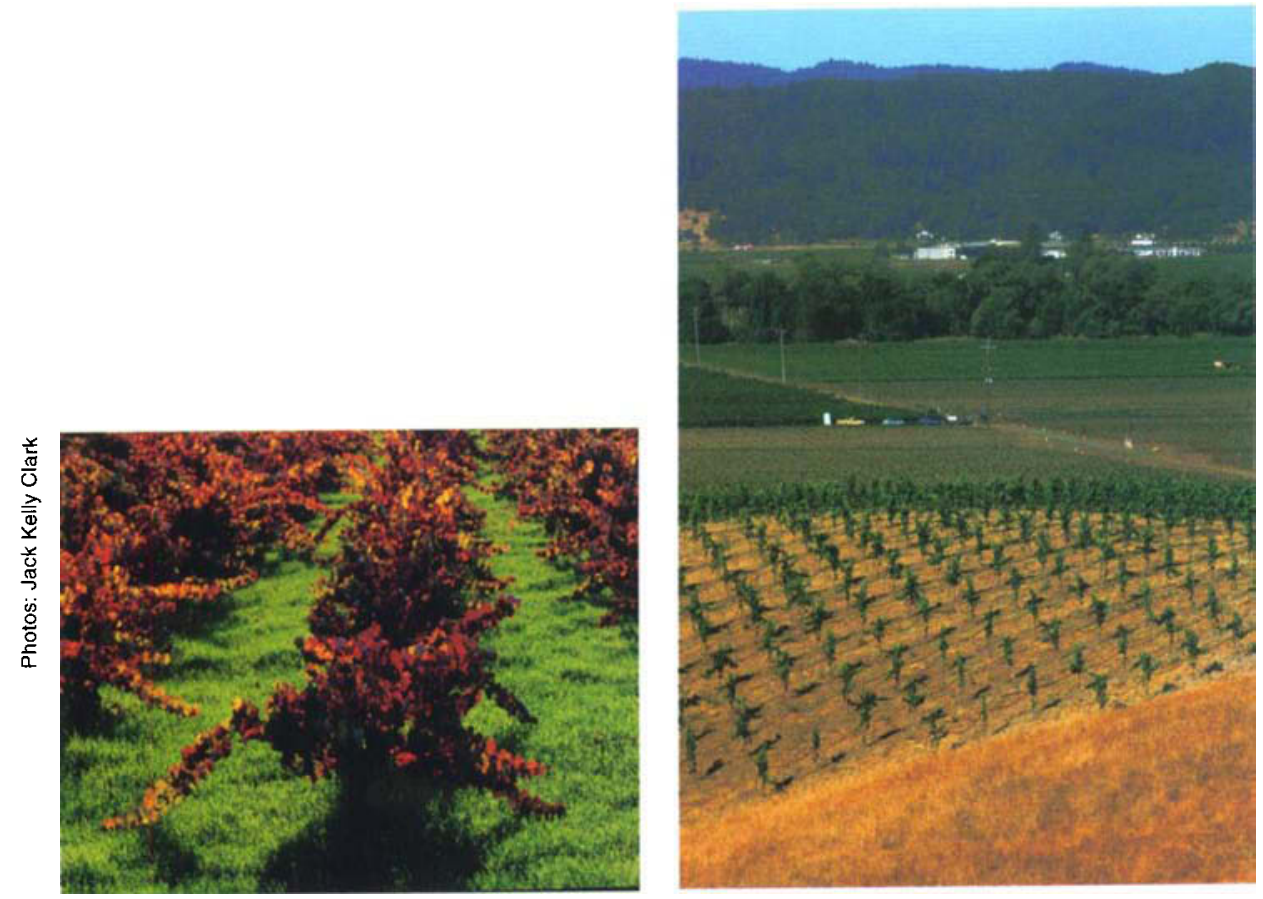

About $10 \%$ of contracts in the wine grape industry are planting contracts, which help growers to secure new financing. Right, A Merlot vineyard has been replanted in the Alexander Valley. Left, An older grapevine.

contracts are not as attractive as those that have price escalator clauses. The results on contract length and price of grapes are not significantly different from zero.

\section{Who uses contracts}

We found that contract usage is widespread in the wine grape industry. More experience, a larger vineyard, more expensive grapes and a longer relationship with the buyer were all related to the higher likelihood of a grower being engaged in a contract. Written contracts, relative to oral contracts, are associated with growers with larger vineyards, more years of experience and fewer premium wine grapes.

In written contracts, we found that provisions related to production practices, price incentives and price determinations are common. Particularly, penalties are more common than bonuses for the enforcement of certain quality standards. Contracts are more likely to specify production practices in premium grape-growing regions, while price incentive provisions are more common in nonpremium regions. This observation indicates that price incentives are more likely when be accurately observed at harvest. Price incentives for grape characteristics observed at harvest are more likely to be used in the regions with lower grape prices that emphasize sugar content. Furthermore, a fixed price provision is less likely to be included in a planting contract or with an evergreen clause. However, fixed price provisions are more likely with greater farming experience, larger vineyards and fewer years with the same buyer.

\section{R.E. Goodhue is Assistant Professor,} D.M. Heien is Professor, H. Lee is Research Economist and D.A. Sumner is Professor, Department of Agricultural and Resource Economics, UC Davis. Sumner is also Director, UC Agricultural Issues Center. Goodhue, Heien and Sumner are members of the Giannini Foundation of Agricultural Economics. The authors thank Rich Sexton for his useful comments, and the grape growers who particithey provided. important product characteristics can pated in the survey for the information

\section{References}

Barkema A. 1994. New roles and alliances in the U.S. food system. In: Schertz LP, Daft LM (eds.). Food and Agricultural Markets: The Quiet Revolution. National Planning Association, Washington, DC. p 96-117.

Barkema A, Drabenstott M, Cook M. 1993 The industrialization of the U.S. food system. In: Padberg DI (ed.). Food and Agricultural Marketing Issues for the 21st Century. Food and Agricultural Marketing Consortium 93-1. Texas A\&M U, College Station. p 3-20.

Barry P. 1995. Industrialization of U.S. agriculture: Policy, research and education needs. $\mathrm{Ag}$ Resource Econ Rev 24(1):128-35.

Boehlje M. 1995. The 'New' Agriculture. Choices (4th quarter):34-5.

Boehlje M. 1996. Industrialization of agriculfure: What are the implications? Choices (1st quarter):30-3.

Boehlje M, Schrader L. 1998. The industrialization of agriculture: Questions of coordination In: Royer J, Rogers $\mathrm{R}$ (eds.). The Industrialization of Agriculture: Vertical Coordination in the U.S. Food System. Brookfield, VT: Ashgate. p 3-26.

[CDFA] California Department of Food and Agriculture. 1999. Final Grape Crush Report, 1998 Crop. Sacramento, CA.

Drabenstott M. 1994. Industrialization: Steady current or tidal wave? Choices (4th quarter):4-8

Drabenstott M. 1995. Agricultural industrialization: Implications for economic development and public policy. J Ag Applied Econ 27(1):13-20

Goodhue RE. 1997. Agricultural complementarities and coordination: modeling value differentiation and production contracting. UC Berkeley Dept of Agricultural and Resource Economics. Ph.D. dissertation.

Goodhue RE. 1999. Input control in agricultural production contracts. Am J Ag Econ 81(3):616-20.

Goodhue RE, Heien DM, Lee H. 1999. Contract Use in the California Winegrape Economy. UC Agricultural Issues Center, Issues Brief 11. http://aic.ucdavis.edu/oa/briefs/html $4 \mathrm{p}$.

Heien DM. 1999. California Winegrape Production. Agricultural and Resource Economics Update 2(4). www.agecon.ucdavis.edu/outreadh/ areupdate.htm

Knoeber CR. Thurman WN. 1994. Testing the theory of tournaments: An empirical analysis of broiler production. J Labor Econ 12(Aprit): 155-79.

Sumner DA, Bombrun $\mathrm{H}$, Alston JM, Heien DM. In press. An economic survey of the wine and winegrape industry in the United States and Canada. UC Agricultural Issues Center. In: Anderson $\mathrm{K}$ (ed.). Proceedings of Wine Industry Conference, October 2001, Adelaide, Australia.

Urban T. 1991. Agricultural industrialization: It's inevitable. Choices (4th quarter):4-6.

[USDA] US Department of Agriculture. 2000. Contracting in agriculture: An overview of the is sues. Economic Research Service. www.ers.usda.gov/whatsnew/issues/contracting/ 